\title{
PATRIARCHAL FAMILY TENDENCIES AND SOCIO-ECONOMIC AND PSYCHOLOGICAL EFFECTS IN PAKISTAN
}

\author{
Farrah Ahmed \\ $\mathrm{PhD}$ Scholar, Department of Sociology \\ International Islamic University, Islamabad \\ farrahahmed28@gmail.com \\ Amber Ferdoos \\ Assistant Professor, Department of Sociology, \\ International Islamic University, Islamabad \\ Farhan Ahmad Faiz \\ Assistant Professor, Department of Sociology \\ Quaid-i-Azam University, Islamabad
}

\begin{abstract}
Pakistani families are now tended to have more sons than daughters to stabilize their future economic condition. The aim of this research was to assess the reason that set into motion this very phenomenon of sex selection and consequent impacts in the social, economic, and psychological realms. The prime concern was to comprehend how certain cultures manufacture and perpetuate gender roles in general and patriarchal tendencies in particular that are created by individuals within a society who choose to imbue a particular structure with meaning. Hence, such tendencies are constantly toyed with and negotiated by actors subscribing to and questioning them. The supremacy of male child is engineered and hence knitted well into our patriarchal socio-cultural and religious structure from which one cannot be aloof and to escape from this labelling, and to support the practice of non-medical gender selection, 'family balancing' has taken the position. The methods that the researcher used to collect data is constituent of two parts. First part explained rationale of the study design while the second part comprised the detailed description of each sub-part of this design including description of the questionnaire. As approach of the study was quantitative research, sampling of the study was probability sampling technique, data was collected through Face-to-Face structured interview schedule and lastly, analysis was done through SPSS. The study denotes that the son preference is the product of multifaceted psychological, social, and economic causes. It can be concluded that there are psychological, social, and economic causes as well as impacts that comprise some factors which have more importance for the nuance interpretation of the son preference than the overall factors themselves.
\end{abstract}

Keywords: Patriarchy, patriarchal family tendencies, sex selection, son preference, socio-economic, psychological causes and effects.

\section{INTRODUCTION}

Patrirachal family tendency is an attitude of preferring male child to female child. It is a cultural and social construction of unequal power relationship where a society classifies men on the upper (superordinate) position and women on lower (subordinate) position in a social structure. Sen (2015) stated that son preference reflects the valuation of women wherein numbers tell us all how many "Women are missing" in any country. These measures in gender bias mortality are due to sex selective births, abortions or insufficient health care to girl child.

Son preference is also a key to balance family and slow the unsustainable population growth of developing countries. Under developing and underdeveloped regions focus on consumption and working hands, therefore male preference in such regions can be seen prominent among different cultures, families 
or in communities. People desire for more sons than girls not only in rural but in urban or semi urban areas also to get financial support in future by their male offspring. They assume that having more sons leads to effective or bright future and may influence on positive economic development of one's family or society. In Asian countries, such as Pakistan, India, China, Nepal and Bangladesh people now came to know that sustainable family development depends upon more working hands of family members, they do not shock after hearing modern and traditional ways of getting less and qualitative childbearing methods. There are some instrumental and medication treatments to cure women health and to attain desire of having more sons, which usually couples apply while having pregnancy or after delivery. Now people in Asian regions accept family planning, family balancing and child spacing concept for having healthy and male offspring. It has been now accepted in south Asian countries that modern practices to avail son offspring is something useful and beneficial from which family can get ideal and peaceful life.

In Pakistani social fabric, patriarchal families' forsee their future monetary and cognitive benefits by accumulative increase in resources. Human behavior is rational and is hence based upon utility maximization for their economic cost-benefit analysis. Following causes for sex selection such as cost of child, quality importance, generation enhancement, economic stability, investment for future, and capital expenditure leads to the below mentioned effects: son is preferable for future, less daughters' quantity, girl is consumer and costly, son career matters, higher education for sons, daughters are costly (education, career, dowry etc.)

\section{REVIEW OF LITERATURE}

Gilles and Jacobs (2012) analyed that sex selection in favor of boys is a symptom of social, cultural, political, and economic injustices against women, and a manifest violation of women's human rights. Zhenghua et al. (2003) described that in China, South Korea, and Northwest India; the practice of patrilineal families is very rigid. It would be extremely rare for a daughter to inherit land in inheritance. According to Natipodhi (2014), around two million girls under the age of five were estimated to be missing every year, most of them were in Asia. True (2012) conclued that Gender-biased sex selection reflects and fuels a culture of discrimination and violence, and hence must be addressed urgently by all Governments as a matter of human rights. Basu and De Jong (2010) opined that in societies where sexselective abortion is not deemed acceptable, parents continue their fertility as long as the desired number of sons is not attained. Guilmoto (2009) stated that following three conditions are currently coming together in pockets of Pakistani society (1) persistence of patriarchal norms and non-egalitarian gender roles and consequent son preference; (2) fertility decline and preference for smaller families; and (3) technological advances that permit the detection of the sex of the fetus. Bongaarts (2013) Pakistan is second highest son preferring country out of 61 countries examined. Acccording to Sathar et al. (2015), women asked that the ultrasound be repeated to make sure and if they already had any of three daughters, they sometimes started crying. The unhappiness and depression was attributed by respondents to pressure from in-laws and relatives who are displeased and behave poorly with women when they conceive a girl. It was mentioned that sometimes women are even divorced for bearing daughters. Basu and Koolwal (2005) further endorsed that male child plays a pivotal role in determining a woman's stay and say in household and household decisions in terms of permission to decide on the woman's healthcare, ability to visit friends and relatives without permission, ability to spend husband's income and decision to purchase major household items. Hafeez and Quintana-Dom (2018) Gender biased breastfeeding patterns in Pakistan showed that breastfeeding duration increased monotonically with the birth order of the child and at every birth order, boys were breastfed longer than girls. Purewal and Kalra (2010) further compared previous postulate with that of daughters, who, in contrast, are conceived as a financial liability as the family is required to prepare sufficient dowry for their wedding. They represent femininity and thus weakness and will one day belong to the home of another man and should thus be seen as a useless investment. Ganatra, Hirve and Rao (2001) while stated that sons run and support their family expenditures and protect their parents at old stage. They are considered as qualitative member of family to uphold and upgrade the economic condition of family rather than daughters. 
Barber (2000) stated that women feel pressure because in-laws want to see their bloodline continue. They yearn to have the 'family name' passed down through the generations. They've built something they value, such as a family inheritance, and they want to keep it in the family. Woman mobility also becomes restricted by her own self due to the fear of public-shaming and stigmatization, as she remains constantly fearful of probing queries from the people around her regarding the birth of son.

\section{Objectives of the Study}

1. To explore the socio-economic and psychological causes result in strengthening patriarchal family tendencies

2. To analyze the socio-economic and psychological impacts involved in patriarchal family tendencies.

3. See the decline in fertility and preference for son in educated women especially in urban societies

4. Impact of technological advancement that allow the early detection of the sex of the fetus for sex selection in urban societies

5. To analyze the impacts of son preference approach at micro level (women) meso level (at family) and macro level (Society).

\section{METHODS}

Approach of the study was Quantitative in nature. Probability Sampling Technique was used to select the suitable population for the study. For Data Collection, Face to Face interview schedule was used and for Data Analysis, Statistical Data analysis Techniques was used. Inclusion criteria for study was, respondents must be married without compulsion of the date of marriage so that the trends of sex selection can also be described. The respondents must be consulting hospitals specifically in Islamabad for sex selection procedures. As the study focused only on women, therefore, the respondent must be female. While Exclusion Criteria was All males even married or otherwise were not part of this study. All respondents consulting sex-selection procedures outside the Islamabad were not part of this study. All respondents who do not desire for family balancing were not part of this study. The researcher visited all the hospitals in Islamabad where sex selection process was available. In each hospital, the research collected information about whether the hospital was providing the facility of sex selection or not. Those hospitals which were not offering sex selection process were excluded from the sampling criteria. After visits to all the hospitals, public and private, in Islamabad city, the researcher prepared a list of the hospitals which provided the sex selection information and procedures which were 38 in number in twin cities Islamabad/Rawalpindi. The next important step was to select true representatives of the population from each hospital. In order to do so, the researcher had to visit the medical staff that was responsible for sex selection services. The researcher arranged a meeting with the concerned staff / authorities / doctors and briefed them about the research purpose. It was explained that the collected data would not be use other than research purpose and the name of any of the staff member would not be disclosed except his/her permission where necessary. The staff was also described that the research would not cause any harm to the dignity of the hospitals and professionalism of the staff.

After taking permission from the concerned staff / authorities / doctors who are responsible for sex selection services, the researcher arranged the above-mentioned time framework for data collection while considering the availability of doctors and the respondents.

The next important step was to select the true representatives of the population. However, before the selection of a sample, the sample size determination was important. Thus, the researcher selected Taro Yamane sample size equation which is as follow:

Where:

$$
n=\frac{N}{1+N e^{2}}
$$

$\mathrm{N}=$ Population size

$1=$ Constant number

$\mathrm{e}=$ Margin of Error 
As target population of the study were married women having the tendency of sex selection, the population size of the married women was required, which the author acquired from Pakistan Demographic and Health Survey 2017-18. The married women in accordance with the survey were 6277 in Punjab. The researcher used the married women number in Punjab because the married women in Islamabad capital (103) produced a very small sample size i.e., 82 respondents. Even reducing the margin of error to 0.01 , the resulted sample size was 101 which the researcher believed is a small sample size for her study. However, using a larger population size provide higher chances of the big sample size and higher number of representatives from Islamabad. Thus, the researcher determined the sample size of the study using number of married women in Punjab which is as follows:

$$
\begin{gathered}
n=\frac{6277}{1+6277(0.0025)}=376 \\
n=376
\end{gathered}
$$

As the confidence of internal is $95 \%$, therefore, the margin of error in the equation is 0.05 . The resulted sample size for the study was 376. However, considering the resources and to improve the validity of the generalization, the researcher increased the sample size to 390 respondents.

\section{DATA ANALYSIS}

Table 1. Relationship between Respondent's Education and family structure for male preference

\begin{tabular}{|l|c|c|c|c|c|c|}
\hline & & Nuclear & Joint & Extended & Chi-square & P-value \\
\hline \multirow{5}{*}{ Education } & Illiterate & 4 & 21 & 8 & & \\
\cline { 2 - 5 } & Middle & 10 & 26 & 4 & & \\
\cline { 2 - 5 } & Matric & 27 & 37 & 10 & \multirow{4}{*}{13.172} & \multirow{3}{*}{0.0214} \\
\cline { 2 - 5 } & FA/FSc & 13 & 27 & 11 & & \\
\cline { 2 - 5 } & BA/BSc & 19 & 42 & 18 & & \\
\cline { 2 - 5 } & $\begin{array}{c}\text { MA/MSc } \\
\text { and Above }\end{array}$ & 24 & 63 & 26 & & \\
\hline
\end{tabular}

Table describes the association between education and the pressure due to patriarchal family pressure (pressure from joint families). A relationship was observed for different levels of education along family structure by using Chi-square test. The frequency of nuclear, joint and extended family for education status of illiterate, middle, matric, FA/FSc, BA/BSc, MA/MSc and above were those who nuclear with: illiterate 4, middle 10, matric 27, FA/FSc 13, BA/BSc 19, MA/MSc and above 24 and joint family were with illiterate 21 , middle 26 , matric $37, \mathrm{FA} / \mathrm{FSc} 27, \mathrm{BA} / \mathrm{BSc} 42$, MA/MSc and above 63 , Similarly the frequency of extended family under different education degrees like as: 8, 4, 10, 11, 18 and 26 for illiterate, middle, matric, FA/FSc, BA/BSc, MA/MSc and above, respectively. From the results, it was evident that more educated and career orientated women were involved in patriarchal tendencies (son preference) due to patriarchal family pressure (pressure from joint families)

After applying chi-square test, it was revealed that there was significant relationship between education status and demand of family structure of son i.e., nuclear, joint, and extended at $5 \%$ level of significant $(\mathrm{p}<0.05)$ with the chi-square test for association its value 13.172.

Table 2. Relationship between sex selection of the fetus and Technological advancement

\begin{tabular}{|c|c|c|c|c|l|}
\hline & & Yes & No & Chi-square & P-value \\
\hline \multirow{4}{*}{$\begin{array}{c}\text { Technological } \\
\text { advancement }\end{array}$} & Strongly agree & 89 & 19 & \multirow{2}{*}{3.104} & 0.0414 \\
\cline { 2 - 4 } & Agree & 35 & 18 & & \\
\cline { 2 - 4 } & Undecided & 22 & 39 & & \\
\cline { 2 - 4 } & Disagree & 19 & 32 & & \\
\cline { 2 - 4 } & Strongly disagree & 14 & 103 & & \\
\hline
\end{tabular}

Table expresses the association between the variables sex selection of the fetus and technological advancement (detection of the fetus) under five different options. A relationship was observed for these 
variables using chi-square test. The frequency of sex selection and technological advancement with options like as strong agree, agree, undecided, disagree and strongly disagree were for yes 14, 22, 35, 19, and 89 and with no status 19, 18, 39, 32, and 103. Therefore, we concluded that technological advancement (detection of the fetus) plays important role in sex selection of the fetus. On the behalf of chi-square test, we come to know that there was a significant relationship between sex selection of the fetus and technological advancement at $5 \%$ level of significance $(\mathrm{p}<0.05)$ with chi-square statistic is 3.104 .

Table 3. Correlation matrix of predictors and outcome variables

\begin{tabular}{|c|c|c|c|c|c|c|c|c|c|c|c|}
\hline Sr. \# & Variables & 1 & 2 & 3 & 4 & 5 & 6 & 7 & 8 & 9 & 10 \\
\hline 1 & Personal Causes & & & & & & & & & & \\
\hline 2 & Interpersonal Causes & -.078 & - & & & & & & & & \\
\hline 3 & Psychological Impacts & ${ }_{*} .638^{*}$ & $.143^{* *}$ & - & & & & & & & \\
\hline 4 & Son Preference & $.535^{*}$ & -.084 & $.548^{*}$ & - & & & & & & \\
\hline 5 & Religious Impositions & $.249^{*}$ & $-135^{* *}$ & $.340^{*}$ & $.266^{*}$ & - & & & & & \\
\hline 6 & Spouse Education Gap & $.141^{*}$ & .046 & .081 & $.109^{*}$ & -.074 & - & & & & \\
\hline 7 & Both Sex Preference & .035 & $.124^{*}$ & .006 & -.018 & -.029 & -.023 & - & & & \\
\hline 8 & Patriarchy & \begin{tabular}{|l}
$.390^{*}$ \\
$*$
\end{tabular} & -.086 & $.452^{*}$ & $.459^{*}$ & $.256^{*}$ & .029 & $.109^{*}$ & - & & \\
\hline 9 & $\begin{array}{l}\text { Nutritional } \\
\text { Discrimination }\end{array}$ & $.356^{*}$ & -.050 & $.449^{*}$ & $.390^{*}$ & $.419^{*}$ & .016 & $.136^{*}$ & $.329^{*}$ & - & \\
\hline 10 & Economical Causes & $.393^{*}$ & -.070 & $.448^{*}$ & $.516^{*}$ & $.228^{*}$ & $.174^{*}$ & $.104^{*}$ & $.357^{*}$ & $.470^{*}$ & - \\
\hline 11 & Economic Impacts & $.295^{*}$ & -.072 & $.392^{*}$ & $.388^{*}$ & $.337^{*}$ & .030 & .020 & $.312^{*}$ & $.445^{*}$ & .526 \\
\hline
\end{tabular}

Table comprised the results of bivariate correlation of the predictors and outcomes. The table showed that personal psychological causes are significantly positively correlated with psychological impacts, son preference, religious impositions, spouse education gap, patriarchy, nutritional discrimination, economic causes, and economic impacts ( $p<.001)$. However, these causes are not significantly correlated with interpersonal psychological causes and both sexes' preferences ( $p>.05)$. Interpersonal psychological causes are significantly positively related with both sexes' preference $(p<.05)$ but significantly negatively related with psychological impacts and religious impositions $(p<.001)$.

Psychological impacts are significantly positively correlated with son preference, religious impositions, patriarchy, nutritional discrimination, economic causes, and economic impacts ( $p<.001$; $p<.05$ ). However, these causes are not significantly correlated with spouse education gap and both sexes' preference. The son preference is significantly positively correlated with religious impositions, spouse education gap, patriarchy, nutritional discrimination, economic causes, and economic impacts ( $p<.001)$. Religious impositions are significantly positively correlated with patriarchy, nutritional discrimination, economic causes, and economic impacts $(p<.001)$. Spouse education gap is significantly positively correlated with only economic causes $(p<.001)$. Interestingly, both sexes' preference is significantly related with economic impacts, but it significantly positively correlated with patriarchy, nutritional discrimination, and economic causes $(p<.001 ; p<.05)$. Patriarchy is significantly positively correlated with nutritional discrimination, economic causes, and economic impacts of sex selection $(p<.001)$. Further, 
nutritional discrimination is significantly positively correlated with economic cause and impacts ( $p<.001)$, and economic causes are significantly positively correlated with economic impacts $(p<.001)$.

Table 4. Model Summary

\begin{tabular}{|c|c|c|}
\hline-2 Log likelihood & Cox \& Snell $\mathrm{R}^{2}$ & ${\text { Nagelkerke } \mathrm{R}^{2}}^{2}$ \\
\hline 461.64 & 0.104 & 0.143 \\
\hline
\end{tabular}

Table comprised the results of the binary logistic regression analysis incorporating predictors of the preference of male child. In the analysis, the researcher coded preference of male child in sex selection $=1$, and no preference of male child in sex selection $=0$. The model summary results showed that -2 Log Likelihood value $=461.64$, Cox and Snell $R^{2}=0.104$ and Nagelkerke $R^{2}=0.143$. These model fit measures are also called pseudo $\mathrm{R}^{2}$ values because the data in the model are not continuous measured. However, the model summary showed suitable fit of the models

The results of the binary logistic regression showed that age group 36-40 is 5.6 times highly likely preferring male child comparing with married women below the age of 20 . The table also showed that those married women who have B.A education are 2.8 times highly likely preferring male child than the illiterate married women. Interestingly, the married women earning 20001-40000 PKR per month are 0.5 times highly likely preferring male child than those women who did not earn at all. Similarly, those married women who were earning 60001-80000 PKR per month are 0.304 times highly likely preferring male child than those who did not earn at all.

In terms of the spouse income per month, the results showed that couples earning less than 20000 up to 80000 PKR per month wanted having male child in their families. The odd ratios of these allincome groups are almost similar. However, the highest odd ratio is of the income group 40000-60000 PKR per month which is 0.027 .

Table 5. Exploratory factor analysis on psychological causes of sex selection

\begin{tabular}{|l|l|l|}
\hline Variables & \multicolumn{2}{|c|}{ Components } \\
\cline { 2 - 3 } & Personal & Interpersonal \\
\hline Absence of son producing any kind of guilt in your mind & .803 & \\
\hline Absence of son causes aggression in you & .796 & \\
\hline $\begin{array}{l}\text { Absence in family balancing approach causes any blaming between } \\
\text { spouses }\end{array}$ & .747 & \\
\hline $\begin{array}{l}\text { Psychological pressure is because of communication gap between } \\
\text { spouses }\end{array}$ & .705 & \\
\hline Attitude of husband towards family planning techniques & & .766 \\
\hline Consideration of husband towards family balancing approach & & .743 \\
\hline Husband's attitude towards wife in terms of family balancing approach & & .647 \\
\hline Eigenvalues & 2.505 & 1.562 \\
\hline$\%$ of variance & 35.792 & 22.313 \\
\hline
\end{tabular}

Note: Factor loading less than 0.50 are suppressed

Table 25 showed the results of the exploratory factor analysis on the psychological causes of the sex selection. The principal component analysis extraction method was used, along with varimax with Kaiser Normalization for rotation methods. The results showed that the two resultant factors explained $58.1 \%$ variance in the data. The first latent factor was labelled personal causes (Eigenvalue $=2.505, \%$ of variance $=35.8 \%$ ) and second latent factor was labelled interpersonal causes (Eigenvalue $=1.6, \%$ of variance $=22.3 \%$ ).

The research used only those items in this analysis which were measured on likert scale to satisfy the assumptions of exploratory factor analysis. Those factors which were not significantly loaded on any of the latent factors were excluded from the analysis. Table 22 comprised the results of the psychological causes of the exploratory factor analysis. 
Furthermore, the research also applied exploratory factor analysis on psychological impacts which produced only one latent factor, therefore, she preferred to compute all the items of this variables which formed a composite variable of psychological impacts.

Table 6. Exploratory factor analysis on social causes of sex selection

\begin{tabular}{|c|c|c|c|c|}
\hline \multirow[t]{2}{*}{ Variables } & \multicolumn{4}{|c|}{ Components } \\
\hline & Son Preference & $\begin{array}{l}\text { Religious } \\
\text { Imposition }\end{array}$ & $\begin{array}{l}\text { Spouse } \\
\text { Education gap }\end{array}$ & $\begin{array}{l}\text { Daughter or both } \\
\text { sex preference }\end{array}$ \\
\hline $\begin{array}{l}\text { Sons are important for social support } \\
\text { in your old age }\end{array}$ & .707 & & & \\
\hline $\begin{array}{l}\text { Any sort of discrimination in } \\
\begin{array}{l}\text { absence of family balancing } \\
\text { approach }\end{array}\end{array}$ & .669 & & & \\
\hline $\begin{array}{l}\text { Appropriate stay in old age with } \\
\text { sons rather than with daughters }\end{array}$ & .668 & & & \\
\hline $\begin{array}{l}\text { Having more sons in family is } \\
\text { prestigious in society }\end{array}$ & .655 & & & \\
\hline Family structure affects sex selection & .577 & & & \\
\hline $\begin{array}{l}\text { Relationship between family size, } \\
\text { sex selection and religion }\end{array}$ & & .855 & & \\
\hline $\begin{array}{l}\text { Religion supports sex selection of } \\
\text { males }\end{array}$ & & .830 & & \\
\hline $\begin{array}{l}\text { Education gap matters in difference } \\
\text { of opinion regarding family planning }\end{array}$ & & & .864 & \\
\hline \begin{tabular}{|lll}
$\begin{array}{l}\text { Spousal education } \\
\text { selection }\end{array}$ & affects & sex \\
\end{tabular} & & & .861 & \\
\hline $\begin{array}{l}\text { People do sex selection in desire for } \\
\text { girls, too }\end{array}$ & & & & .784 \\
\hline Better to have both sexes in family & & & & .763 \\
\hline Eigenvalues & 2.537 & 1.682 & 1.282 & 1.197 \\
\hline$\%$ of variance & 23.062 & 15.287 & 11.658 & 10.882 \\
\hline
\end{tabular}

Note: Factor loading less than 0.50 are suppressed

Table comprised the results of exploratory factor analysis on the social causes of sex selection. The researcher used principal component analysis as an extraction method. The varimax rotation method with Kaiser Normalization was applied in the analysis. The exploratory factor method produced four latent factors of social causes which explained almost $61 \%$ of the variance in the data.

The first factor labelled as son preference has eigenvalue of 2.54 which explained $23.1 \%$ of the variance in the data. The second factor has the eigenvalue of $1.7(\%$ of variance $=15.3 \%)$ which was labelled as religious impositions as the items in the factor are highly related with religion. The third factor was labelled spouse education gap (eigenvalue $=1.28, \%$ of variance $=12 \%$ ) and the fourth factor was tagged as daughter or both sexes preference (eigenvalue $=1.2, \%$ of variance $=11 \%$ ).

Table comprised the results of the simple linear regression analysis on the patriarchy as outcome variable. The $\mathrm{R}^{2}$ of this regression model showed that the predictors explained $28 \%$ variance in the data. The One-Way Analysis of Variance also showed that the variables are significantly different across the outcome variable, $F(7,382)=20.9, \mathrm{p}<.001$.

The table showed that personal psychological causes $(\beta=0.13)$ significantly predicted the patriarchy $(\mathrm{p}<.001)$ which depicted that one-unit increase in the personal psychological causes of sex selection is highly likely to strengthen the established patriarchy by 0.13 units. 
Table 7. Predictors of social causes of sex selection: patriarchy

\begin{tabular}{|c|c|c|c|c|c|c|}
\hline \multirow[t]{2}{*}{ Variables } & \multirow[t]{2}{*}{ Sub Variables } & \multicolumn{2}{|c|}{$\begin{array}{l}\text { Unstandardized } \\
\text { Coefficients }\end{array}$} & \multirow{2}{*}{\begin{tabular}{|l|}
$\begin{array}{l}\text { Standardized } \\
\text { Coefficients }\end{array}$ \\
Beta
\end{tabular}} & \multirow{2}{*}{$\mathrm{T}$} & \multirow{2}{*}{$P$} \\
\hline & & $\mathrm{B}$ & Std. Error & & & \\
\hline & Constant & 1.679 & .715 & & 2.347 & .019 \\
\hline \multirow{2}{*}{$\begin{array}{l}\text { Psychological } \\
\text { Causes }\end{array}$} & Personal Cause & .127 & .041 & .163 & 3.077 & .002 \\
\hline & Interpersonal Cause & -.061 & .071 & -.038 & -.858 & .391 \\
\hline \multirow[t]{4}{*}{ Social Causes } & Son Preference & .198 & .039 & .287 & 5.077 & .000 \\
\hline & Religious Imposition & .131 & .056 & .109 & 2.344 & .020 \\
\hline & Spouse Educational Gap & -.050 & .070 & -.032 & -.717 & .474 \\
\hline & $\begin{array}{|llll|}\begin{array}{l}\text { Daughter } \\
\text { preference }\end{array} & / & \text { Box } & \text { sex } \\
\end{array}$ & .181 & .077 & .104 & 2.342 & .020 \\
\hline \multicolumn{2}{|c|}{ Economical causes } & .059 & .028 & .112 & 2.129 & .034 \\
\hline
\end{tabular}

The social causes also significantly related with patriarchy as one-unit increase in the son preferences is highly likely to strengthen the established patriarchy by 0.198 units. Similarly, one-unit increase in the religious impositions, highly likely to support the existed patriarchy by 0.131 units. However, spouse educational gap is not significantly related with the outcome variable. Interestingly, the preference of both sexes and daughter also significantly related with the patriarchy $(p<.05)$.

Lastly, the economic causes are highly likely strengthening patriarchy by 0.059 units. However, the results showed that the preference of is the one of the most important predictors of patriarchy as it has the highest coefficient value.

Table 8. Predictors of nutritional discrimination

\begin{tabular}{|c|c|c|c|c|c|c|}
\hline \multirow[t]{2}{*}{ Variables } & \multirow[t]{2}{*}{ Sub Variables } & \multicolumn{2}{|c|}{$\begin{array}{l}\text { Unstandardized } \\
\text { Coefficients }\end{array}$} & \multirow{2}{*}{\begin{tabular}{|l} 
Standardized \\
Coefficients \\
Beta
\end{tabular}} & \multirow{2}{*}{$\mathrm{T}$} & \multirow{2}{*}{$P$} \\
\hline & & B & $\begin{array}{l}\text { Std. } \\
\text { Error }\end{array}$ & & & \\
\hline & Constant & -.273 & .504 & & -.541 & .589 \\
\hline \multirow{2}{*}{$\begin{array}{l}\text { Psychological } \\
\text { Causes }\end{array}$} & Personal Cause & .065 & .029 & .111 & 2.226 & .027 \\
\hline & Interpersonal Cause & .021 & .050 & .017 & .417 & .677 \\
\hline \multirow[t]{4}{*}{ Social Causes } & Son Preference & .053 & .027 & .103 & 1.939 & .053 \\
\hline & Religious Imposition & .269 & .039 & .298 & 6.824 & .000 \\
\hline & Spouse Educational Gap & -.046 & .050 & -.040 & -.937 & .350 \\
\hline & \begin{tabular}{|l|l}
$\begin{array}{l}\text { Daughter / Box sex } \\
\text { preference }\end{array}$ & \\
\end{tabular} & .141 & .054 & .108 & 2.581 & .010 \\
\hline \multicolumn{2}{|c|}{ Economical causes } & .119 & .020 & .302 & 6.088 & .000 \\
\hline
\end{tabular}

Table consisted of the results of simple linear regression analysis to explore the significant predictors of nutritional discrimination of women who desired to have son children in their family. The $\mathrm{R}^{2}$ value of the model showed that the predictors explained $36 \%$ of the variance in the data. The One-Way analysis of variance revealed significant difference of the predictors across outcome variables, $F(7,382)$ $=30.7, p<.001$.

The results showed that personal psychological causes are significantly related with nutritional discrimination $(\mathrm{p}<.05)$. However, interpersonal psychological causes are not significantly related with the outcome variable $(\mathrm{p}>.05)$. 
The social causes are also significantly predicted nutritional discrimination as the results showed that one-unit increase in the son preference is highly likely to increase nutritional discrimination by 0.053 units. Similarly, one-unit increase in religious impositions is highly likely to increase nutritional discrimination by 0.27 units. Further, the preference of daughter and both sexes is also correlated with nutritional discrimination $(p<.001)$.

However, spouse educational gap was not significantly associated with the outcome variable (p>.05). Lastly, the economic causes also significantly predicted nutritional discrimination $(p<.001)$. Interestingly, the results showed that religious impositions of son preferences in family is the most important predictor of nutritional discrimination as it has the highest beta value.

Table 9. Predictor of economic impacts of sex selection

\begin{tabular}{|c|c|c|c|c|c|c|}
\hline \multirow[t]{2}{*}{ Variables } & \multirow[t]{2}{*}{ Sub Variables } & \multicolumn{2}{|c|}{$\begin{array}{l}\text { Unstandardized } \\
\text { Coefficients }\end{array}$} & \multirow{2}{*}{$\begin{array}{l}\begin{array}{c}\text { Standardized } \\
\text { Coefficients }\end{array} \\
\text { Beta }\end{array}$} & \multirow{2}{*}{$\mathrm{T}$} & \multirow{2}{*}{$P$} \\
\hline & & $\mathrm{B}$ & Std. Error & & & \\
\hline & Constant & 4.812 & .972 & & 4.949 & .000 \\
\hline \multirow{2}{*}{$\begin{array}{l}\text { Psychological } \\
\text { Causes }\end{array}$} & Personal Cause & .032 & .056 & .029 & .579 & .563 \\
\hline & Interpersonal Cause & .000 & .097 & .000 & -.003 & .998 \\
\hline \multirow[t]{4}{*}{ Social Causes } & Son Preference & .102 & .053 & .104 & 1.919 & .056 \\
\hline & Religious Imposition & .346 & .076 & .202 & 4.544 & .000 \\
\hline & Spouse Educational Gap & -.100 & .096 & -.045 & -1.042 & .298 \\
\hline & \begin{tabular}{|lll}
$\begin{array}{l}\text { Daughter } \\
\text { preference }\end{array}$ & Boy sex \\
\end{tabular} & -.045 & .105 & -.018 & -.432 & .666 \\
\hline \multicolumn{2}{|c|}{ Economical causes } & .318 & .038 & .424 & 8.415 & .000 \\
\hline
\end{tabular}

Table consisted of the results of simple linear regression analysis on economic impacts of sex selection. The $\mathrm{R}^{2}$ value of the model showed that the predictors explained $34 \%$ of the variance in the outcome variable. The One Ways Analysis of Variance also showed that the predictors are significantly different by outcome variable, $F(7,382)=27.9, p<.001$.

The results of this model produced very interesting results as it showed that most of the variables did not significantly predict the economic impacts of sex selection except one religious impositions and economic causes. More interestingly, both predictors have almost similar importance in predicting economic impacts of sex selection as the coefficient value of religious imposition is 0.35 and economic causes is 0.32 . It also showed that religious impositions have higher importance than economic causes in economic effects of sex selection.

\section{CONCLUSION}

A number of cultural, social, and economic factors influence the relative Cost and Benefits of sons and daughters in society ultimately lead parents to gender preferences. There is huge pressure on women to produce sons... which not only directly affects women's reproductive choices and decisions, with implications for their health and survival, but also puts women in a position where they must perpetuate the lower status of girls through son preference

It is also women who has to bear the consequences of giving birth to an unwanted girl child. These consequences can include violence, abandonment, divorce or even death. Against the backdrop of such intense pressure, women seek to discover the sex of a fetus through ultrasound. The discovery of a female fetus can then lead to its abortion. Sex selection can also take place before a pregnancy is established, or after the birth of a girl, through child neglect or infanticide. Over decades, the practice has caused a sex-ratio imbalance in many countries particularly in South Asia, East Asia and Central Asia including Pakistan. 


\section{SUGGESTIONS}

There is strong need to work on diffused norms and believes regarding sexual division via institutions. Social and Behavior Change Communication to Reduce Son Preference. Legislation to Restrict Fetal Sex Disclosure. Sensitization and Training of Healthcare Providers. Engage influential opinion leaders to address son preference. There is need to create Gender sensitization via National curriculum

\section{REFERENCES}

Barber, N. (2000). Why parents matter: Parental investment and child outcomes. Greenwood Publishing Group.

Basu, A. M., \& Koolwal, G. B. (2005). Two concepts of female empowerment: Some leads from DHS data on women's status and reproductive health. A focus on gender-Collected papers on gender using DHS data, ORC Macro, Calverton MD, 15-33.

Basu, D., \& De Jong, R. (2010). Son targeting fertility behavior: Some consequences and determinants. Demography, 47(2), 521-536.

Bongaarts, J. (2013). The implementation of preferences for male offspring. Population and Development Review, 39(2), 185-208.

Ganatra, B., Hirve, S., \& Rao, V. N. (2001). Sex-selective abortion: Evidence from a community-based study in western India. Asia-Pacific Population Journal, 16(2), 109-124.

Gilles, K., \& Feldman-Jacobs, C. (2012). When technology and tradition collide: From gender bias to sex selection. Washington, DC: Population Reference Bureau.

Guilmoto, C. Z. (2009). The sex ratio transition in Asia. Population and Development Review, 35(3), 519549.

Hafeez, N., \& Quintana-Domeque, C. (2018). Son preference and gender-biased breastfeeding in Pakistan. Economic Development and Cultural Change, 66(2), 179-215.

Natipodhi, P. (2014). The practice of sex selection in Asian region (No. 034). Asian Law Institute Working Paper Series.

Purewal, N. K., \& Kalra, V. S. (2010). Women's 'popular' practices as critique: Vernacular religion in Indian and Pakistani Punjab. In Women's Studies International Forum, 33 (4), 383-389. Pergamon.

Sathar, Z., Rashida, G., Hussain, S., \& Hassan, A. (2015). Evidence of son preference and resulting demographic and health outcomes in Pakistan.

Sen A. (2015). The idea of justice: A response. Philosophy \& Social Criticism. 41(1), 77-88. doi:10.1177/0191453714553501

True, J. (2012). The political economy of violence against women. Oxford University Press.

Zhenghua, J., Das Gupta, M., Bohua, L., Zhenming, X., Chung, W., \& Hwa-Ok, B. (2003). Why is son reference so persistent in East and South Asia? A cross-country study of China, India and the Republic of Korea. The Journal of Development Studies, 40(2), 153-187. 